\title{
The Effect of Meta - Creative Learning Strategies toward Student's Creative Products Practiced Creativity and Creative Self - Efficacy in Making Women's Clothing in Vocational High School
}

\author{
Rahmiati \\ Departement of Makeup and Beauty \\ Faculty of Tourism and Hospitality \\ Universitas Negeri Padang \\ Padang, Indonesia \\ rahmiati@fpp.unp.ac.id
}

\author{
Saemah \\ Fakulti Pendidikan \\ Universiti Kebangsaan Malaysia \\ Selangor, Malaysia \\ saemah@ukm.edu.my
}

\begin{abstract}
This study aims to determine the effectiveness of meta-creative learning strategies on the achievement in fashion's creative products, practiced creativity, and creative self-efficacy among vocational high schools' student. This research used the quasi-experimental design using a non-equivalent control-group design (pre-test and post-test). The subjects consist of 104 students, 52 students of experimental group and 52 students of control group. The questionnaires were used to assess creativity practice and creative self-efficacy, while creative product of women's fashion is measured using scoring rubric. The data was analyzed using descriptive statistics (average and standard deviation) and inferential statistic (MANOVA and multiple regressions). The results analysis showed positive significant effect of meta-creative learning strategy in improving student's achievement on women's fashion products and creative selfefficacy. As its appropriateness, meta-creative strategy according to the level of achievement, the interaction effects analysis showed that meta-creative strategy is effective to improve students' creativity practice and creative self-efficacy for both low and high achievement groups but not for improving performance in creative product. The results indicated that metacreative strategy is more suitable for high achievers to improve performance in creative product.
\end{abstract}

Keywords-meta-creative, learning strategies, products creative, practiced creativity, creative self - efficacy, making Women's Clothing in vocational high school

\section{INTRODUCTION}

The process of education is very important to develop human's quality [1]. Therefore, creative thinkers and learners are needed in the community for the country in the future. There are seven skills are needed to start new world of work in $21^{\text {st }}$ century. One of them is critical thinking and problem solving skills [2]. As the result, creativity, critical thinking and problem solving are important skills needed in the world of work. A creative individual can generate new ideas and be able to solve a problem.

Personal creativity of students is very important to get through the development of technology and innovation which are growing rapidly today [3]. It has been recognized by all groups: leaders, businessmen, scientists, historians, educators and psychologists, that creativity is important to the survival of education in a country especially in this era of globalization where the changes, challenges and competition is ongoing and will continue to apply [4].

Developing of creativity is necessary in making women's clothing fashion products at Vocational High School (SMK). National Standards for Family and Consumer Sciences (NASAFACS 2008-2018) competence in the field of fashion clothing is specialized to the knowledge and skills needed in clothing. The most important knowledge to get involved in the fashion industry is trading knowledge, design knowledge and knowledge of textiles [5]. Knowledge regarding designing, creative and innovative is very important aspects to treat each custom. It is because of this competence related to mutually with cognitive style development process during the visualization process of clothing design in form of twodimensional into three-dimensional [6]. In the business of fashion clothing to help companies compete in the market, a process of fashion design that need to be owned/ by a designer namely; (1) understand the interests of users; (2) proficiency to innovate; (3) proficiency do design (modeling); (4) the speed in producing; (5) the method of distribution; and (6) promotion activity [7]

Through subjects making clothes for women in vocational high schools in majoring clothing, students are expected to produce a creative product fashion by mastering skills in designing, choosing appropriate textiles, making basic patterns, changing the basic pattern into appropriate pattern 
based on the design, adopting the pattern, set the pattern on the base material, cutting, marking and sewing, good and appropriate technical competence in finishing. Based on the results obtained from the students' task, it showed that fashion products produced by students were not reached the standards set by the school so it becomes a challenge for the school, especially teachers subject of women's clothing. Other weaknesses are sometimes teachers set model / design of clothing that will be done by students because if each student creates a different model, it will be difficult for teachers to check the results. Students didn't have self-efficacy yet to create ideas in fashions, to determine which textiles are appropriate accordance with the shape of the body and the time of consumption. Self-efficacy is a key element of social cognitive theory; it seems to be an important variable studying because it will influence student's motivation to learn [8] [9]. Numerous studies show that efficacy affects student's achievement and learning behavior in the aspect of their choice, energy, perseverance and achievement [9].

Aptitude and non-aptitude traits associated with creativity were distinguished by [10]. Aptitude trait or creative thinking rather than creativity includes smoothness, suppleness, and originality in thinking. When someone is able to do creative achievement, it is determined by the characteristics of nonaptitude (affective) including self-confidence, perseverance, aesthetic appreciation and independence [11]. Students with creative thinking ability will be able to produce creative products. This capability can be seen from the process in generating creative and new ideas. Students are expected to show their creativity in making a quality woman's clothing in accordance with the design, body size, the appropriate sewing techniques, and beautiful and attractive accessories on it. It is necessary to apply the process of creative thinking and creative achievements.

Based on the explanation above, it is important to develop the creativity in making products in form of women's clothing in Vocational High School (SMK) because it is related to the creative design process. Creative design process is part of the design process, because it can be considered as a process that leads to creative output [12]. Developing creativity in learning of making women's clothing requires appropriate learning strategies to allow the students generate new ideas, new ways, invented a new form, a new model or something better than before. A creative output refers to ideas or goods as the result of the process of creative thinking [13].

The process of creative thinking was developed by Graham Wallas in 1926 which is the most famous [14] [15]. Creative problem-solving process by Wallas comprised four (4) phases namely preparation, incubation, illumination and verification. Creative thinking process involves divergent thinking (fluency, flexibility and originality in thinking).

Beside creative ability possessed by the students for the determination of a learner's creativity, [16] also states that the classroom can foster the creativity of students, which means those teachers' teaching strategies in the classroom, can enhance the creativity of students. Students' creativity can be enhanced or developed through the learning process implemented by the teacher. Teachers should create a good lesson plan, and they need to give directions to the students.

The study conducted [6] explains that a more effective student is a student who uses meta-cognitive strategies in learning process. According to them, this strategy may explain how someone learns, builds goal-setting, self-regulation and is able to make customizations to execution of tasks or activities. In addition, this strategy is very useful to help improve students' learning productivity. It is in line with [17] who stated that through meta-cognitive strategies, students have the opportunity to make a reflection in learning. This can be done by knowing the students' strengths and weaknesses, how they learn, how to set goals, and learning itself.

Meta-creative strategy in this study is a process of learning by combining the stages of the creative process, namely: preparation, incubation, illumination and verification by using reflection meta-cognitive namely to design, monitor and assess in thinking creatively in solving problems of making women's clothing.

A product is the result of the creativity process [18]. Studies about a product were conducted to see the results of art and culture such as music, drama, poetry and science results from the point of the creativity [19][20]. Assume that the studies of the product are objective and as the result, it can be measured scientifically [18] [21]. It is in line with Besemer \& O'Quin in [39] who presented a framework to assess product conjecture shapes and three-dimensional innovation namely the originality, resolution, elaboration and synthesis. Creative products can be classified into three categories, namely: (1) novelty; (2) resolution, and (3) elaboration) and (4) synthesis [23]. Novelty includes the original product and its potential to generate more ideas and a change, which means that to what extent the product is new, in terms of numbers and spacious new processes, new techniques, new materials, new concepts, creative products in the future. Products are made is original, few among which have been made by others, and also caused a surprise.

A creative product in this study is the result of women's clothing made by the students will be assessed based on: novelty, resolution, elaboration, and synthesis.

The practiced creativity is an activity that is done as a habit or performed repeatedly in doing something or routine work. If someone does a continuous practiced creative consistently, he will be able to improve his proficiency. Practiced activity is an aspect of creativity put into practice, by using the competency and skill of creativity [24] and [25]. It is one of the components being seen in this study which were associated with creativity in making women's fashion. The practiced creativity can be defined as an opportunity to use creative competence and skill in the workplace [26]. In the previous studies, the aspect of creative potential was related to the practiced creative, but the result of the study showed that there was significant difference between creative potential and practiced creative [26][27]. This distinction is important 
because if someone is able to see themselves as having creative potential, they will not show the competency to practice the potential and as the result, they will be less in getting involved to act creatively.

The term of practiced creativity in this study is defined as the sensitivity of students against him as well as the surrounding matter to practice thinking process to generate creative ideas while learning to make women's fashion. The creativity that will be performed by the students, referring to Torrance's opinion [11], which described that an individual creativity is seen from the 4-dimensional namely fluency, flexibility, originality and elaboration.

Self-efficacy is the personal belief that one is capable of performing in an appropriate and effective manner to attain certain goals. The concept of self-efficacy is actually based on social cognitive theory proposed by [28] which emphasizes the role of observational learning, social experience, and reciprocal determination in personality development and defines self - efficacy as a determinant of how people feel, think, motivate themselves and behave.

Efficacy itself as someone own perceptions about how good his/her self may function in certain situations, selfefficacy relates to beliefs that someone has the ability to perform the desired action [29]. Self-efficacy is as one aspect of self-knowledge or self-knowledge of the most influential in human life [30].

Self-efficacy creative or individual views are on their own effort to be creative [31] [22] [33]. There is a linkage between the creative self-efficacy with one's creativity. A study of [34] showed that creative self-efficacy was related to the involvement of creative work. Reference [35] reported a positive relationship between efficacy creative itself and creative achievements of students. Furthermore, Choi found creative self-efficacy was entirely influenced by the efficacy of the individual (personality, ability and motivation).

Based on the explanation above, it can be concluded that creative self-efficacy is a person's belief of individuals in his effort to carry out tasks that are specific required to produce a novelty, originality or a finishing as appropriate and related to the effect of creative achievements and the effect of self creative thinking related to making women's clothing.

The purpose of this research is to know for sure; (1) the effect of learning meta-creative to the achievement of the creative product, practiced creativity, and students' creative self efficacy in making women's clothing and (2) the interaction between learning strategy phase achievement of students on product creativity, creative self- efficacy, and practiced creativity of students in making fashion women's clothing.

\section{METHODS}

The method of this research was quasi - experimental research with non equivalent control group design with pretest and post-test. The research was conducted at twelfth grade students in two vocational schools (SMK) majoring tourism in West Sumatera. The sample was chosen by using random sampling technique. There were 104 students were chosen as the sample taken from two vocational schools (SMK) in West Sumatera.

The instrumentations of this research were practiced creativity, creative self-efficacy and scoring rubric to see the product. The practiced creative inventory was adapted from Eason [36]. The inventory of the effect of meta-creative learning strategy was in line with creative self-efficacy inventory. This research focused on Creative-Thinking SelfEfficacy and Creative Performance Self- Efficacy [31] [33]. The treatment was conducted in 8 weeks or 8 meetings and divided into two sections namely theoretical learning and practical learning by using meta-creative learning strategy.

The data were analyzed by using descriptive statistics and inferential statistics. Statistics descriptive was used to describe the achievement of creative product, practiced creativity and creative self-efficacy. Inferential statistics used in this research was MANOVA to test the hypotheses: (1) there is no significant different between students' average achievement score in Women's Fashion product, practiced creativity and creative self-efficacy in experimental and control classes in before and after the treatment, and (2) there is no interaction between learning strategy with steps of learning towards students' creative product, creative self- efficacy and practiced creativity in making women's clothing.

\section{RESULT AND DISCUSSION}

Table 1 presents the descriptive analysis for average score and standard deviation of pre-test, the achievement of women's fashion products, creative self-efficacy, and the practice of creativity following the experimental group and the control group. For experimental group, the average score of women's fashion creative product variable was 3.60 , the standard deviation was 0.314 . The average score in control group was 3.54 and standard deviation was 0.318 . The average score of creative self-efficacy variable in experimental group was 3.65 , standard deviation was 0.378 . The average score in control group was 3.66, standard deviation was 0.274 . The average score of the students' achievement of practiced creativity in the experimental group was 3.40, standard deviation was 0321 and the average score for students in control group was 3.40 and the standard deviation was 0.326 .

TABLE I. AVERAGE SCORE FOR DEPENDENT VARIABLE IN PRE-TEST

\begin{tabular}{|l|l|l|l|l|}
\hline \multicolumn{2}{|c|}{ Strategies } & $\begin{array}{c}\text { Average } \\
\text { Score }\end{array}$ & $\begin{array}{c}\text { Standard } \\
\text { Deviation }\end{array}$ & N \\
\hline $\begin{array}{l}\text { Creative } \\
\text { Product }\end{array}$ & Meta-Creative & 3.60 & .314 & 52 \\
\hline & Conventional & 3.51 & .243 & 52 \\
\hline $\begin{array}{l}\text { Creative self- } \\
\text { efficacy }\end{array}$ & Meta-Creative & 3.65 & .378 & 52 \\
\hline & Conventional & 3.77 & .297 & 52 \\
\hline
\end{tabular}


Table I, Cont.

\begin{tabular}{|l|l|l|l|l|}
\hline $\begin{array}{l}\text { Practiced } \\
\text { creativity }\end{array}$ & Meta-Creative & 3.36 & .348 & 52 \\
\hline & Conventional & 3.45 & .301 & 52 \\
\hline
\end{tabular}

The result of MANOVA showed that there is no significant difference between creative product of women's clothing, $\mathrm{F}(1.102)=1.211, \mathrm{P}=0.274$; practiced creativity $\mathrm{F}$ $(3,101)=0.001 \mathrm{P}=0.981$ between both strategies in pre-test. The result also showed that there is no different average score for creative product and practiced creativity significantly between both strategies in pre-test.

For hypotheses testing, the researcher used Multivariate Analysis (MANOVA). The result showed that there is significant effect of the strategies, $\mathrm{F}(2,100)=10.368(\mathrm{~A}), \mathrm{P}=$ 0.000 ; Result of Pillai's Trace $\left.=0.237, \eta^{2}=0.080\right]$; and practiced creativity $\left[\mathrm{F}(1,102)=26.176, \mathrm{p}<0.0167, \eta^{2}=\right.$ 0.204 . It was not the factor of creative self-efficacy $[\mathrm{F}(1,102)$ $\left.=421, \mathrm{p}>0,00167, \eta^{2}=0.0040\right]$; for students.

TABLE II. THE RESULT OF UNIVARIAT BETWEEN THE EFFECT AND STRATEGIES

\begin{tabular}{|c|c|c|c|c|c|c|c|}
\hline Source & Variables & $\begin{array}{c}\text { Type } \\
\text { III Sum } \\
\text { of } \\
\text { Squares }\end{array}$ & Df & $\begin{array}{l}\text { Average } \\
\text { Squared }\end{array}$ & $\mathrm{F}$ & sig. & $\eta^{2}$ \\
\hline 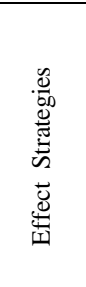 & $\begin{array}{l}\text { Creative } \\
\text { product } \\
\text { Creative } \\
\text { self - } \\
\text { efficacy } \\
\text { Practiced } \\
\text { creativity }\end{array}$ & 1.358 & 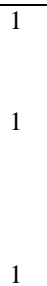 & $\begin{array}{l}1.358 \\
.419\end{array}$ & 8.810 & .004 & .040 \\
\hline
\end{tabular}

\section{A. The Effect of Meta-Creative Strategy toward Creative Product for Women's Clothing}

The result of the statistical analysis shows that there is a significant difference in average achievement scores for creative products between the meta-creative strategy and conventional strategy. It shows that the Meta - creative strategy gives the effect to the achievement of the creative product. Average value of women's fashion creative product test by using meta-strategy creative was 3.79, standard deviation was 0.332 , while the conventional strategy average score was 3.56 , and standard deviation was 0.445 . Based on the result, the comparison between the effects of strategy to the achievement of the creative product by using Meta creative strategy versus conventional strategy is 0.080 (simple) [37].

To ensure the result, there is a difference average score of women's fashion creative product at a significant level $\mathrm{p}$ $<0.0167$ analysis MANOVA test through the Test of BetweenSubject Effects can explain the result. The result of analysis showed that Meta creative learning strategy is a significant factor to women's fashion products $[\mathrm{F}(1,102)=8.810, \mathrm{p}$ $<0.0167]$.

The difference in average score indicates the achievement of women's fashion products for group of meta-creative learning strategies is higher than the conventional strategy group at post-test (Table. 3). Therefore, this study was able to rule out the hypothesis that there was no significant difference in average score of women's fashion creative product achievement between students of Meta creative strategies with the conventional group.

TABLE III. DIFFERENCES OF AVERAGE ACHIEVEMENT SCORES OF CREATIVE PRODUCTS BETWEEN STRATEGY GROUPS

\begin{tabular}{|c|c|c|c|c|c|c|c|}
\hline \multirow{2}{*}{$\begin{array}{c}\text { Bound } \\
\text { Variable }\end{array}$} & \multirow{2}{*}{$\begin{array}{c}\text { (I) } \\
\text { Strategy }\end{array}$} & \multirow{2}{*}{$\begin{array}{c}(\mathrm{J}) \\
\text { Strategy }\end{array}$} & \multirow{2}{*}{$\begin{array}{c}\text { Ave. } \\
\text { Dif } \\
\text { I-J }\end{array}$} & \multirow{2}{*}{ 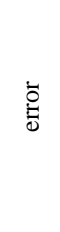 } & \multirow[t]{2}{*}{ Sig } & \multicolumn{2}{|c|}{$\begin{array}{c}\text { Confidence } \\
\text { level } \\
95 \%\end{array}$} \\
\hline & & & & & & ڤี & s \\
\hline \multirow{2}{*}{ 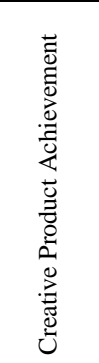 } & $\begin{array}{l}\text { Meta- } \\
\text { creative } \\
\text { Learning } \\
\text { Strategy. }\end{array}$ & $\begin{array}{l}\text { Conventi } \\
\text { onal } \\
\text { Learning } \\
\text { Strategy. }\end{array}$ & .229 & .007 & .004 & .381 & .076 \\
\hline & $\begin{array}{l}\text { Conventi } \\
\text { onal } \\
\text { Learning } \\
\text { Strategy. }\end{array}$ & $\begin{array}{l}\text { Meta- } \\
\text { creative } \\
\text { Learning } \\
\text { Strategy. }\end{array}$ & -.229 & .007 & .004 & -.076 & -.381 \\
\hline
\end{tabular}

The effect of Meta creative strategy in making simple Women's Fashion can be explained by the creative process proposed by [38] through four phases namely: preparation, incubation, illumination / generating the ideas, and the verification. As implemented in the module of meta - creative learning strategy used in this study, preparation phase is a phase where the students prepare to solve problems in making women's fashion by preparing, gathering information, studying the patterns of thinking of others and assessing data relating to the manufacture of fashion, For example, in determining the shape of women's fashion invention that will be created by students, in the beginning, student look for some designs from magazines, books, on the internet, and also look into clothing sales stores. Existing knowledge e about the requirements related to making clothing, such as conditions rather than concoct forms, Textile / Fabric in accordance with the shape of the body and its consumption time, the personality of the customer become students' observation. Observation is an action to look with interest and meaningful. A case that attracted the attention will be given pedestal and a serious concern [39].

Meta-cognitive strategy through the designing, monitoring and evaluation is a way of learning to improve thinking ability accompanied by the guidance of teachers through the 
processes used by the students to observe their own learning, cognitive activity escort, and to ensure that a cognitive objectives are met. It is in line with a major component of the process of thinking and creativity includes meta-cognitive skills in the designing, monitoring and evaluation [40].

\section{B. The Effect of Meta - Creative Strategy toward Creative Self-Efficacy}

Based on the result of statistical analysis, there was no difference of average scores between experimental group with control group. The average score of creative self- efficacy by using Meta - cognitive strategy is $3.81 \mathrm{~min}$, and standard deviation is 0.363 , and for the conventional strategy is 3.68 for average score and standard deviation is 0.255 .

To ensure the descriptive analysis, MANOVA test through the Test of Between-Subject Effects was used to see whether there are differences in average score for creative self-efficacy at a significant level $\mathrm{p}<0.0167$ or not. The analysis result shows that Meta - creative learning strategy is not a factor to students' creative self-efficacy $[\mathrm{F}(1,102)=4,251, \mathrm{p}>$ $0.0167]$.

The difference in average score indicates a creative selfefficacy for learning strategies group of meta-creative is same / almost compared to the conventional strategy group at posttest (Table 4). However, the findings cannot reject the null hypothesis stating that there was no significant difference in average score of self-efficacy among students creative strategy creative act with the conventional group.

TABLE IV. DIFFERENCES OF AVERAGE SCORES OF CREATIVE SELFEFFICACY BETWEEN STRATEGY COLLECTION.

\begin{tabular}{|c|c|c|c|c|c|c|c|}
\hline \multirow{2}{*}{$\begin{array}{c}\text { Bound } \\
\text { Variable }\end{array}$} & \multirow{2}{*}{$\begin{array}{c}\text { (I) } \\
\text { Learning } \\
\text { Strategy }\end{array}$} & \multirow{2}{*}{$\begin{array}{c}(\mathrm{J}) \\
\text { Learning } \\
\text { Strategy }\end{array}$} & \multirow{2}{*}{$\begin{array}{l}\text { Ave. } \\
\text { Dif } \\
\text { I-J }\end{array}$} & \multirow{2}{*}{ 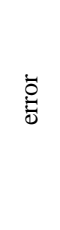 } & \multirow[t]{2}{*}{ Sig } & \multicolumn{2}{|c|}{$\begin{array}{c}\text { Confidence } \\
\text { level } \\
95 \%\end{array}$} \\
\hline & & & & & & ڤే & s \\
\hline \multirow{2}{*}{ 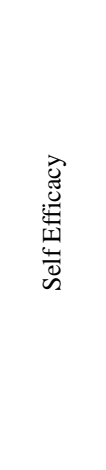 } & $\begin{array}{l}\text { Meta- } \\
\text { Creative }\end{array}$ & $\begin{array}{l}\text { Conventi } \\
\text { onal } \\
\text { Meta- } \\
\text { Creative }\end{array}$ & .127 & .062 & .042 & .249 & .005 \\
\hline & $\begin{array}{l}\text { Meta- } \\
\text { Creative } \\
\text { Conventi } \\
\text { onal }\end{array}$ & $\begin{array}{l}\text { Conventi } \\
\text { onal } \\
\text { Meta- } \\
\text { Creative }\end{array}$ & -.127 & .062 & .042 & -.005 & -.249 \\
\hline
\end{tabular}

The average score of students' creative self-efficacy in the experimental group is the same with the students in control group in post-test. However, hypothesis null that states there are no significant average scores differences between students' creative self - efficacy in the experimental and control group cannot be rejected. They have same average score. The effect size for creative self - efficacy is low (0:04) [37]. To maximize and develop the creativity, a self-efficacy is needed [41]. The influence of self - efficacy on cognitive processes also allows a person to develop the ability to think creatively in proposing the new ideas and problem solving.

The results show that there is no average score differences between experimental and control group students in terms of creative self-efficacy. This creative meta strategy is not unable yet to improve the students' efficacy in making a female fashion significantly, probably due to meta - creative learning only run during 8 weeks. Students aged between $16-18$ years still have thoughts that are not fixed, which is easily influenced by environments such as peers, teachers and family and easy to change. This is in line with the views of social cognitive theory, self - efficacy is a trait that is not fixed; it is a dynamic and can be changed directly related to the specific work domain [42].

\section{The effect of Meta - Creative Learning Strategy toward Practiced Creativity}

Based on the statistical analysis, there are differences average score in practiced creativity between students in the experimental and control group. The average score of students in the experimental group is 3.86 , and standard deviation is 0.329 , while the conventional group is 3.56 for average score and the standard deviation is 0.256 .

To ensure the result, MANOVA test through the Test of Between-Subject Effects was used to see there are differences in the practiced creativity average score at a significant level $\mathrm{p}$ $<0.0167$. The data analysis showed that Meta - creative learning strategy is a significant factor to students' women's fashion creative product $[\mathrm{F}(1,102)=26176, \mathrm{p}<0.0167]$.

The result shows that there are significant differences between the average score of practiced creativity creative in the experimental and control group $\mathrm{p}=0.000, \mathrm{p}<0.0167$. The different average score indicates the practiced creativity for Meta creative learning strategies group is higher than the conventional strategy group. It means that the null hypothesis that states there are no significant differences in the practice of creativity min score between students in the experimental and control group is rejected. The size effect for creative selfefficacy is 0.204. According to Cohen, 0.16 is high [37]. 
TABLE V. AVERAGE DIFFERENCE OF CREATIVITY PRACTICED BETWEEN STRATEGY GROUPS

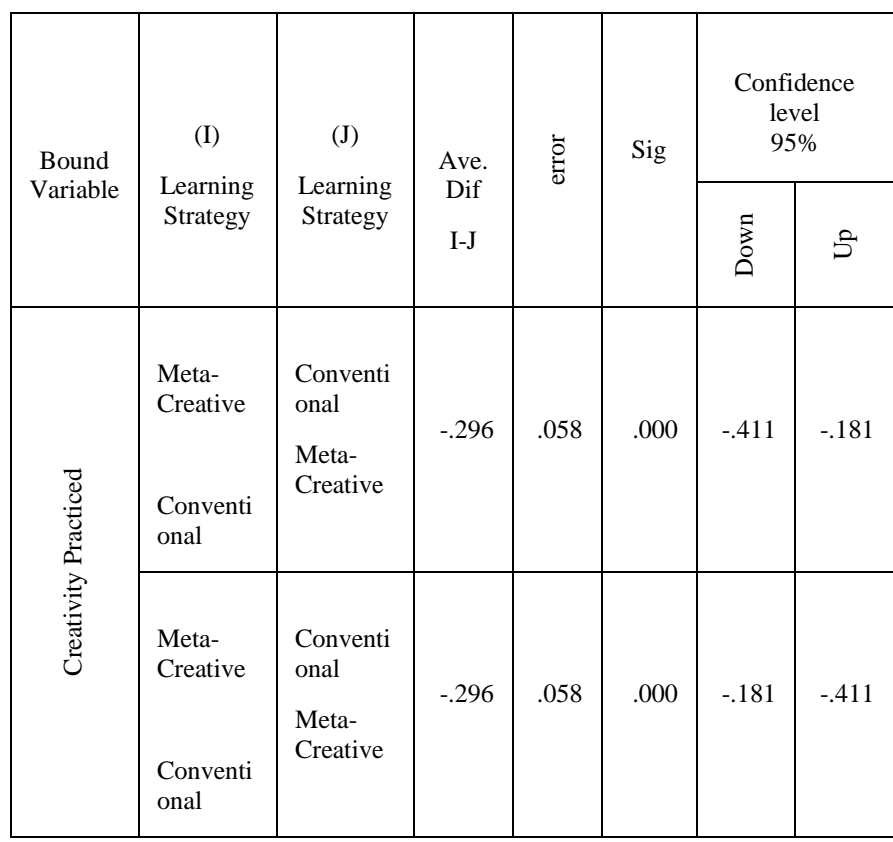

The effect of Meta - creative strategy through the creative use of meta-cognitive process element in thinking creatively is capable to improve the students' practiced creativity in the completion of making creative women's clothing. The practiced creativity is the sensitivity of a person to solve problems and explore ideas creatively [36]. It can be seen from the results of fashion products made by the students. The students made different design, tried new ideas that they got in preparation phase. Based on the result of studies, Women's Fashion made by the students is different in form of the design, materials/ textiles and the accessories. The students see the opportunities by using their mind and skills to generate new ideas in making Women's Clothing based on the design that has been drawn. It is in line [26] who state that practiced creativity is defined as seeing opportunities to use the skills and creativity in doing something.

\section{The Interaction between Meta - Creative Learning Strategy and Creative Product Achievement, Creative Self- Efficacy and Practiced Creativity}

The results of a descriptive comparison of achievement between pre-test and post-test based on learning strategies and achievement stage show there are differences between average score of dependent variable namely: creative product, creative self-efficacy and practiced creative. The results shows an increase in value of the post-test as well as pre - test in the practiced creativity, creative self - efficacy and creative product for students with high and low achievement for both learning strategies (creative strategy and conventional strategy).

The difference of average score is based on high achievement with low achievement in meta-cognitive and conventional strategy. The average scores of students with high and low achievement are 0.22 and 0.17 . The score is decreased (-) about 0.27 for students in control group in posttest for high achievement, and for students with low achievement is 0.23 .

For creative self-efficacy, the students' score increase for students with high and low achievement for both strategies. For Meta - creative learning strategy, the score of students with high and low achievement increase 0.16 and 0.15 for conventional strategy, it is 0.01 and 0.03

The results also show that an increase in practiced creativity for students of high and low in meta-creative strategy is 0.38 and 0.50 . For the conventional strategy, it is 0.19 for students with high achievement and 0.13 with low achievement. The students' achievement in the experimental class was improved better than the conventional strategy.

Based on the result of the Test of Effect between Subject analysis, it also shows that there is an interaction between the strategies with creative products achievement, $[\mathrm{F}(1,103)=26$ $\left.265, \mathrm{p}<0.0167, \mathrm{\eta}^{2}=0208\right]$. The result also shows that there is no interaction between the strategies and creative selfefficacy, $\left[\mathrm{F}(1,103)=0.092, \mathrm{p}>0.0167, \eta^{2}=001\right.$, and the practice of creativity $\left[\mathrm{F}(1,103)=0557 \mathrm{p}>0.0167, \eta^{2}=0.06\right.$.

TABLE VI. UNIVARIATE ANALYSIS VARIABLES EFFECT BETWEEN SUBJECTS

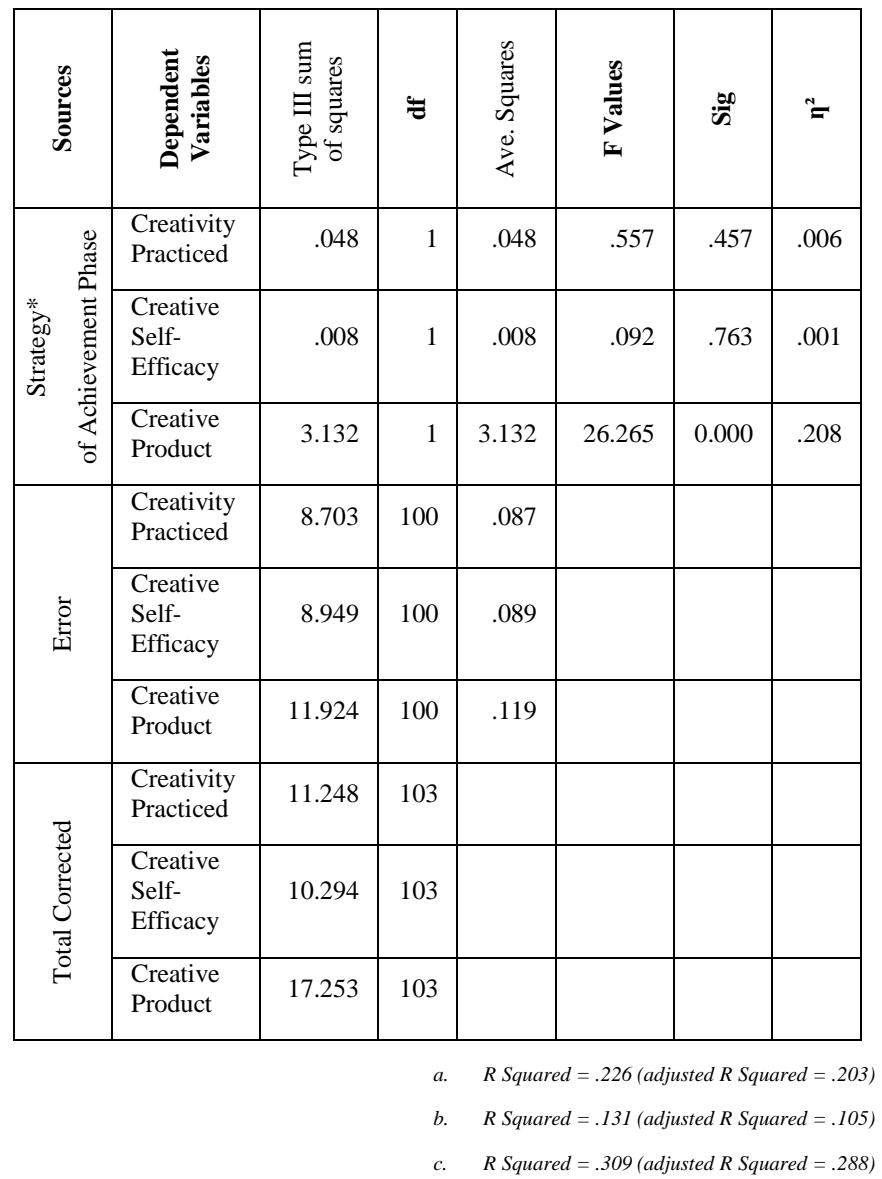


Based on the explanation above, the hypothesis "there is no interaction between learning strategies and student achievement towards practiced creativity, and creative self efficacy" is accepted. However, there is an interaction learning strategies and students achievement toward creative product. It means that, Creative Meta learning strategy is appropriate for both students who have high achievement and low achievement for practiced creativity and creative self-efficacy. For creative product, creative learning strategies is appropriate for students who have high achievement and less suitable for students who have low ability. It means that meta-creative learning strategy in learning women fashion can improve their achievement without consider the creative self-efficacy and practiced creativity. This result is in line with [43]. He suggests meta-cognitive learning holds one of the crucial roles of learning in order to succeed. The structure of the implementation of this strategy in learning how to make fashion women through group discussions / conversations in a group can enhance the understanding of student and improve product / creative work. Relation to the Meta creative strategies in the classroom, that the learning process in making women's fashion emphasizes the use of meta-cognitive learner according to the Meta creative learning theory. Students can learn actively, and confident during the learning process because teachers develop meta-cognitive strategies [44].

There is an interaction between learning strategies and the achievement of the stage for fashion's creative product variable. This means meta- creative is appropriate strategy for students with high achievement, it will be not appropriate applied to students who have low achievement. It showed that the smart teenage students got good grades during creative exam given compared with those who are less intelligent students.

In the implementation of meta-creative strategy for students with low ability, the students' involvement is needed in teaching and learning process. It can be done by improving meta-cognitive skills in designing, monitoring and evaluating the learning process and organize their thoughts.

\section{CONCLUSION AND SUGGESTION}

\section{A. Conclusion}

These results indicate that the Meta creative learning strategies used in the learning process in making women's fashion in Vocational High School Department majoring fashion gives the effect to the achievement of the creative product, practiced creativity of students and did not give the effect to students' creative self-efficacy. Teacher's learning strategy is a factor to increase the achievement scores of creative products and practiced creativity and is not a contributing factor to the increase in creative self-efficacy. The learning strategy can be applied in the same study at other schools to be able to practice creativity in generating creative product in making beautiful, interesting and different clothing from the others. The results also indicate there is an interaction strategy with achieving the creative product, and there is no interaction between learning strategies and students' achievement toward the practiced creativity, and creative self efficacy. Therefore, creativity must be developed in future education today in order to facilitate students to enter the world of work which is increasingly challenging.

\section{B. Suggestion}

Teachers in majoring fashion should give freedom to the students in teaching and learning process to be more creative in choosing the design of clothing, textiles and accessories to create clothing task by giving instructions. Teachers also have high creativity in the learning process and role to assist and build the students to be aware to use their own thinking processes in solving problems creatively in order to be a generation who can competes in the global era. Further studies need to be conducted to improve learning in vocational education which is still more concerned with making clothing for kids and form men

\section{ACKNOWLEDGMENT}

The writer would like to thank to Sekolah Menengah Kejuruan Negeri 6 Padang and SMK Negeri 3 Payakumbuh for the cooperation and willingness to give opportunity to conduct this research. Furthermore, thanks to Dr. Ruslin Amir, Dr. Shahlan Surat, Prof. Dr. Mujiran, Dra. Ernawati, M.Pd, Weni Nelmira, M.Pd.T, Sri Wardani, M.Pd, Dra. Yenimar, and Winarti, S.Pd who have gave contribution in creating learning module of Woman Clothing.

\section{REFERENCES}

[1] Yahya Buntat \& Noor Sharliana. Factor-faktor yang Mendorong Kreativiti di Kalangan Pelajar, Universiti Teknologi Malaysia. Jurnal Pendidikan Teknologi Konseling. 2(1):175-208, 2011.

[2] Wallas, G. The art of tought. London: J. Cape, 1926.

[3] Mohamad Sattar Rasul, Nur Farhana waheeda Ramli, Rose Amnah Abd Raul. Pembentukan Karektor Pelajar Kreatif Mengikuti Teori Sternberg: Suatu Analisis Kandungan dan Pembangunan Kerangka Konseptual. Jurnal Teknologi, 2013.

[4] Mohamad Mohsin Mohamad Said \& Nasruddin Yunos. Halanganhalangan Kepada Usaha Memupuk Kreativiti di Kalangan Pelajar. Jurnal Pengajian Umum. (7 (1): 41-51, 2008.

[5] Arasinah Kamis., \& Ab. Rahim Bakar. Technical and generic skills and knowledge competencies required to participate in the clothing industry as well as the expected changes on the fashion trends. Dalam Prosiding persidangan Kebangsaan Penyelidikan dan Inovasi dalam Pendidikan dan Latihan Teknik dan Vokasional, pada 16-17 November, 2011 (pp. 342-347). Hotel Naza Talyya Pulau Pinang, 2011.

[6] Arasinah. Kebolehan visualisasi spatial pelajar Rumah Tangga khusus dalam bidang rekaan fesyen. Dalam Rosini Abu, Anis Zakariah, \& Nor Faradillah Piee @ Shafiee, Aliran Pedagogi dan Penyelidikan dalam Pendidikan Ekonomi Rumah Tangga (pp. 55-76). Serdang, Selanggor: Penerbit Universiti Putra Malaysia, 2012.

[7] Sinha, P. Creativiti in Fashion. Journal of Textile and Apparel. Technology and Management.Volume 2, Issue, Fall 2002. pp 1-16, 2002. 
[8] Pajeras, F. Self-efficacy beliefs in academic settings. Review of Educational Research, 66 (4), 543-578, 1996.

[9] Schunk, D. H. Self-efficacy for reading and writing: Influence of modeling, grad seeting and self-evaluation. Reading and Writing Quartely: Overcoming Learning Difficulties, 19 (2), 159-172, 2003.

[10] Guilford, J.P. The Nature of Human Intelligence. New York: McGrawHill, 1967.

[11] Utami Munandar, Pengembangan Kreativitas Anak Berbakat. Jakarta:Penerbit PT Gramedia Pustaka Utama, 2004

[12] Wong, Y. L \& Siu. K. L. M. A Model of creative design process for fostering creativity of students in design education. School of Design, The Hongkong Polytechnic University, Hung Hom, Kowloon, Hongkong. Published online:25 March 2011. 2011

[13] Warr, A. M. Undestanding and Supporting Creativity in design (Unpublished doctoral dissertation). Bath, U. K: University of Bath. 2007.

[14] Howard, T. J., Culley, S. J., \& Dekoninck, EDescribing the creative design process by the integration of engineering design and cognitive psychologi literatur, Design studies, 29. 160-180, 2008.

[15] Howard-Jones, P. A. A dual-state model creative cognition for supporting strategies that foster creativity in the classroom. International Journal of Tecnology and Design Education, 12(3), 215-226, 2002.

[16] Beghetto, R. A. Creativity in the Classroom. Dalam. J. C. Kaufman and J.R Sternberg, The Cambridge Handbook of Creativity. Hlm. 447-466. Cambridge: Cambride University Press, 2010.

[17] Heather, C. The relationship between metacognition and writing in sixth grade mathematics. Tesis Doctor of Education Teacher Leadeship, Education, Walden University, 2009.

[18] Runco, A. M. Creativity. Annual Review of Psychology, 55, 657-687, 2004.

[19] Moran, Seanna. The roles of creativity in society. Dlm. Kaufman, J. C. \& Sternberg, J. R. (penyt). The Cambridge Handbook of Creativity. Hlm. 74-92. Cambridge: Cambridge University Press, 2010.

[20] Palaniappan, Ananda Kumar. Creativity and academic achievement. Shah Alam: Karisma Publication Sdn Bhd, 2005.

[21] Kozbelt, A., Beghetto, R. A. \& Runco, M. A. Theories of Creativity. Dlm. Kaufman, J. C. \& Sternberg, J. R. (pnyt). The Cambridge Handbook of Creativity. Hlm. 20-47. Cambridge University Press, 2010.

[22] Tan, G. 2006. Desingning Succesful executive Program on Creativity: Theoretical Approaches and Pratical Challenges in Asia. Problems and Perspectives in Management 4(3): 146-154)

[23] Besemer, S.P., \& Treffinger, D.J. Analysis of creative product: Review and Synthesis. Journal of Creativity Behavior, 43, 997-1013.

[24] Amabile,T. Creativity in context: Update to the social psychology of creativity. Boulder, CO: West View Press, 1996.

[25] Hilton, B. L. A Model for the Study of Creative Problem Solving. Journal of Creative Behavior 2 : 133-42, 1968.

[26] DiLiello, T.C., \& Houghton, JMaximizing organizational leadership capacity for the future. Journal of managerial Psychology 21(4) : 319$337, .2006$.

[27] Mumford, M. D \& Gustafson, S. B. Creativity syndrome: Integration, application, and innovation. Psychological Bulletin 103(1) : 27-43, 1988.

[28] Bandura. A. Self Efficacy: The exercise of control. New York: Freeman, 1997.

[29] Alwisol. Psikologi Kepribadian. Malang: Universitas Negeri Muhammadiyah Malang, 2004.

[30] Ghufron, N.M. \&Risnawita. Teori teori Psikologi. Jogjakarta: Ar Ruzz Media, 2014.
[31] Abbott, D.H. Experiencing creative self-efficacies: A case study of Coming Anarchy. Unpublished manuscript, 2009a.

[32] Abbott, D.H. Constructing a Creative Self-Efficacy Inventory: A Mixed Methods Inquiry. University of Nebraska, 2010.

[33] Abbott, D.H. Self-efficacy for creative thinking: A structural equations reanalysis of Gist (1989). Paper to be presented at the American Educational Research Association annual conference, Denver, CO, 2010a.

[34] Carmeli, A., \& Schaubroeck, J. 2007. The influence of leaders' and other references' normative expectations on individual involment in creative work. The Leadership Quarterly. 18, 35-48, 1981.

[35] Choi, J. N. Individual and contextual predictor of creative performance: The mediating role of psychological processes. Creativity Research Journal. 16. 187-199.

[36] Eason, R. 2009. A look at creativity in public and private schools. Thinking Skills and Creativity. 130-137. http://www.elsever.com/lacate/tsc. (25 Jun 2013)

[37] Cohen, J. 1988. Statistical Power Analysis for The Behavioral Science (2nd. Ed). Hillsdale: N.J. Erlbaum, 2004.

[38] Wallas, G. The art of tought. London: J. Cape, 1926.

[39] Mohd Azhar Abd Hamid. Kreativiti konsep, Teori dan Praktis. Johor: Penerbit Universiti Teknologi Malaysia, 2004.

[40] Armbruster, B. Metacognition in creativity. In. J. Glover, R. Ronning, \& C. Reynolds (Eds). Handbook of creativity (pp. 172-182) New York: Plenun Press, 1989.

[41] Sternberg, R. J., \& Williams, W. M. How to develop student creativity. Alexandria, VA: Association for Supervision and Curriculum Development, 1996.

[42] Judge, T.A, Bouderau, J.W., Bretz, R.D. Job and life attitudes of male executives, Journal of Applied Psychology, Vol. 79: 767-782, 1994.

[43] Livingston, J.A. Metacognition: an Overview , (Online) (http://WWW.gse.buffalo.edu/fasp/shuell/cep564/Metacog.htm), diakses Marc 2011, 1997.

[44] Hollinggworth, R. W., \& Mcloughlin, C. Developing Science Student's Metacognitive Problem Solving skill. Journal of Education Teknology. Australian, 17 (1) 50-63, 2001. 